\title{
MANUFACTURING AND PERFORMANCE EVALUAION OF A ALOCAL MACHINE PROTOTYPE FOR HARVESTING SUGAR BEET
}

\author{
A. F. ABED RABOU * ELYAMANI A. E., "AND Z. EMARA*
}

Ag. Eng. Res. Inst. (AEnRI), Giza, Egypt

(Manuscript received 27 December 2011)

\begin{abstract}
A new machine prototype fabricated used in harvesting sugar beets was manufactured and tested to evaluated the perfect suitable performance under Egyptian conditions. The investigated harvester of the present study is a combine machine made from local materials to perform the topping, digging, lifting and uprooting collecting operations of sugar beet roots in one process. The prototype was evaluated in terms of effective field capacity (Fed/h), lifting efficiency (\%), topping efficiency (\%) and harvesting efficiency, (\%). In addition, specific fuel consumption (l/kW.h) and total harvesting cost (LE/fed) were determined. The test experiment parameters were carried out at four forward speeds of $2.16,2.88,3.66$ and $4.32 \mathrm{Km} / \mathrm{h}$ and four topping knife speeds of $3.1,4.3,5.5$ and $6.2 \mathrm{~m} / \mathrm{s}$ with three soil moisture content of 30,24 and $18 \%$ (w.b.). Results of the tests indicated that , maximum effective field capacity was $0.48 \mathrm{fed} / \mathrm{h}$, maximum harvesting efficiency was $88.9 \%$, maximum topping efficiency was $97.9 \%$ and maximum uprooting efficiency was $92.6 \%$ On the other hand, a minimum of specific fuel consumption and total operation cost were $0.517 \mathrm{l} / \mathrm{kW} . \mathrm{h}$ and 73 L.E /fed, respectively.

keywords. Harvesting sugar beet, root yield, harvesting efficiency, topping efficiency, lifting efficiency, total damaged roots, total energy consumed.
\end{abstract}

\section{INTRODUCTION}

Sugar beet is one of the most important crops, not only for sugar production ,but also for producing fodder and organic mater for the soil. Over $40 \%$ of the world, sugar production is produced from sugar beet. Egypt produces around one million tons of sugar annually. Sugar can contribute more than 500,000 ton and the other 500,000 ton is produced from sugar beet. However the local consumption of sugar was about 1.5 million tons accordingly about half million ton have to be imported, Annual Agricultural Statistics Book (2008). The important of sugar beet is not only limited to being a supplement for sugar production but also extend for many economical by products such as animal feed and its other secondary industries. Traditionally, sugar beets are harvested and topped manually. allam et. al., (1988) 
told that, mechanizing the processes of sugar beet harvesting resulted in drastic reduction of $86 \%$ in labor requirement per ton of harvested beets and up to $69 \%$ of harvesting cost . Mady (2001) noticed that, forward speed increasing from 1.9 to 3.6 $\mathrm{km} / \mathrm{h}$, increases the bruised roots from 3.5 to $4.0 \%$, the cut roots from 4 to $4.9 \%$ in addition decreasing the percentage of lifted roots from 90.8 to $89.5 \%$. Abou- shieshaa (2001) reported that the increment in forward and flail rotational speeds increases both broken and overtopping. The minimum value of overtopping and broken beet were 3.42 and $1.15 \%$, respectively at forward speed of $1.83 \mathrm{~km} / \mathrm{h}$ and flail speed of $8.36 \mathrm{~m} / \mathrm{s}$ for mechanical planting and field chopper. Meanwhile, the percentage of under topped was 6.35 under the same conditions. Abd-Rabou (2004) constructed a hold crown leaves of sugar beets. A seriating four star wheels having $25 \mathrm{~cm}$ diameter and there is a $5 \mathrm{~cm}$ horizontal inter lock between these two groups. This inter lock moves the two groups together, and holds the crown leaves of sugar beets. Bentini et. al. (2005) reported that, different techniques have been developed for harvesting sugar beet, the main steps involving the roots from field to sugar factory are reported in figure 1 . The roots in multistage harvesting are normally lifted and then deposited

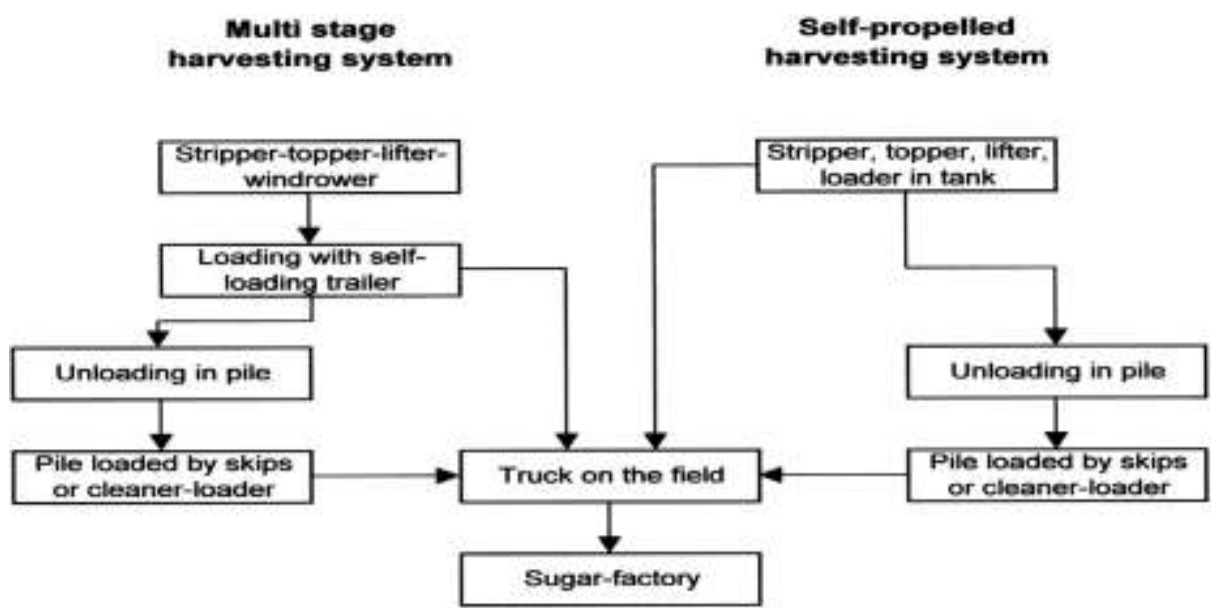

Figure 1. Main harvesting techniques used for sugar beets in Mediterranean countries. Bentini et. al. (2005)

on the ground in windrows, from where they are later collected and lifted onto trucks for transport to the sugar factory. Self-propelled harvesting is done in one of two ways: three- or six-row sugar beet harvesters lift the roots to the tank, from where they are unloaded onto the truck for the factory, or the harvester unloads the sugar beets in piles on the field and the roots are then picked up by cleaner-loaders or skips. In the former method, the roots remain in windrows for some hours because of harvesting logistics and the different work-rate of the machines used in each stage. 
Bahnas (2006) indicated that there is a positive relation among the forward speed and each of field capacity, field efficiency and tops yield. The aim of this study was to develop topper unit for sugar beet foliage and evaluate the possibility of utilizing it under Egyptian conditions. He reported too that mechanical harvest of sugar beet achieved $1.02 \mathrm{Fed} / \mathrm{h}, 68.64 \mathrm{MJ} / \mathrm{Fed}$ and $140.47 \mathrm{~L} . \mathrm{E} / \mathrm{Fed}$ for field capacity, required energy and harvesting costs. While, the traditional (manually) harvest of sugar beet achieved $0.09 \mathrm{fed} / \mathrm{h}, 35.25 \mathrm{MJ} /$ Fed and $286.75 \mathrm{~L} . \mathrm{E} /$ Fed, respectively. Morad et. al. (2007) reported that results reveal that total crop losses as well as harvesting cost are minimum and lifting efficiency is maximum under following conditions:

- Harvesting sugar beet crop under mechanical planting using the sugar beet harvesting machine.

- Harvesting forward speed of between 1.6 to $2.4 \mathrm{~km} / \mathrm{h}$.

- Soil moisture content of between 21 to $24 \%$.

Elbanna et. al. (2010) told that, an economical sugar beet planting and harvesting machine was developed to a rationalized power, and operation cost combined and to be suitable for the Egyptian farm to replace the traditional methods in both planting harvesting operations. The developed machine has two components: first component is planting unit: and the second component is sugar beet pulling unit: this unit is involved three main sugar beet harvester components namely, two appropriate shares for loosing the ridge structure around the roots, pulling out belt mechanism and a proper disk knife as a topping mechanism. The machine performed 60-70 $\mathrm{cm}$ riders during planting two rows. Also harvester one sugar beet row through pulling out and topping mechanisms. Also two proper shares form for loosing the ridge structure around the roots. These components were equipped on a proper mounted one-row harvester frame. Field experiments were carried out to test and evaluate the performance efficiency of the developed planting and harvesting machine under different operating parameters and conditions. The developed machine with 3 $\mathrm{km} / \mathrm{h}$ forward speed, this machine productivity was $0.8-0.85 \mathrm{Fed} . / \mathrm{hr}$. with cost of 70 LE/Fed while harvesting cost for one feddan in about three hours equal $180 \mathrm{LE} / \mathrm{fed}$. The problem is in the lack of sugar beet harvesting machines to the high price and imported from abroad in dollars. Second, home-made aren't combine machines only topping or lifting operation and combine machines assembled were had some problems in the process because the throne topping happen to him during a sliding dragging it up thereby reducing the efficiency of topping levels. The objectives of this work are devoted to:

- Manufacture sugar beet harvester prototype machine suit for topping and lifting of sugar beet in one process under Egyptian conditions. 
- Investigate effects of forward speed, topping knife speed and soil moisture content on field capacity and efficiency, topping efficiency and root yield.

- Determine minimize of damaged roots, total energy consumed and total harvesting cost.

- Determine the optimum condition for operating anew prototype machine.

\section{MATERIALS AND METHODS}

\section{1- Materials}

The sugar beet harvesting machine used in the present study was designed and built at small workshop in kaferelshiekh and it is a single row harvester. The investigated harvester is sketched in Fig (2). The lifting depth was adjusted to be 30 $\mathrm{cm}$ for all treatments under study. And the technical specifications of sugar beet harvester under study were listed in Table (1).Parts of the machine used for harvesting the sugar beet crop carried out three operations for harvesting the sugar beet crop at the same time. These steps are summarized in the following:

A- Topping unit consists of crown leaves holder and two knife cutting disc. Leaves holder consists of four-star wheels. This group is assembled of two shafts and moving by ball bearing .They is fixed the chassis of the machine. Its speed can be changed by pulleys, of various diameters. The diameter of each star wheel is $25 \mathrm{~cm}$ and $5 \mathrm{~cm}$ of thickness. Each two are assembled a moving post of $10 \mathrm{~cm}$ vertical distance. Each of them is fixed a four-noel flange. There is a horizontal inter lock between each adjacent two in a distance of $5 \mathrm{~cm}$. This inter lock moves the two groups together, and holds the crown leaves of sugar beets.The diameter of each knife cutting disc is $25 \mathrm{~cm}$. 

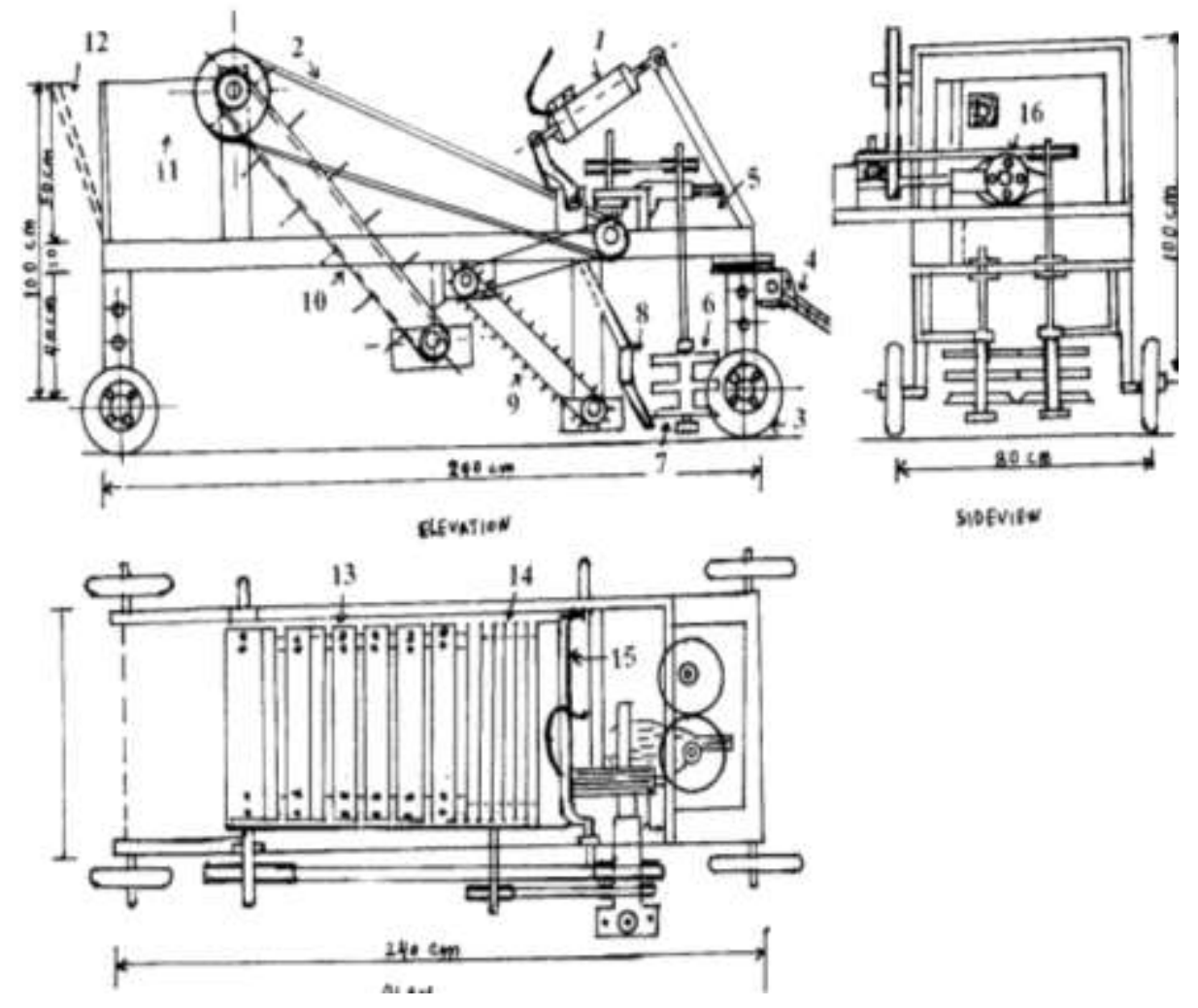
1. Hydraulic piston
9. Transfer of the primary mat beet
2. $V$ - belt
10. Transfer of the secondary mat beet
3. Ground wheel
11. Tank
4. Knuckle
12. Hinged door
5. Take off shaft
13. Cross bar
6. Star wheel
14. Symptoms of iron
7. Knife disk
15. Crank shaft
8. Lifting fork
16. Track idler

Fig. 2. Elevation, side view and plane of the designed Sugar beet harvesting machine. 
B- The shear lifting fixed on an upper crank, and at its end there is a hydraulic piston. When the piston is opened through pressing the oil, the arm is moved behind the group of star wheels for lifting the sugar beet with holding the trellis by the star wheels and the movement of the machine forwards. Hence, the sugar beet is extracted.

C- Beet elevator unit consists of two beet elevator the first is a set of iron bars installed on the two tracks and is intended to bring down the outstanding soil and the second to lift the roots to the collecting tank. Beet collecting tank has a back door, it opens downwards by a hinge, we can put on overturn part to it so as to become able to unload the beet completely.

Also, Gearbox was fixed on the front of the main frame to transmit the rotary speed from the tractor P.T.O. by a universal joint to the implement spinner. The gear box consists of two gears fixed on the two perpendicular shafts. When the universal joint is engaged between P.T.O. shaft and gear box shaft the resulting ratio. Frame (chassis) was reinforced with four corners. It was manufactured from U-shape iron of $100 \times 50 \times 5 \mathrm{~mm}$ with length of $240 \mathrm{~cm}$, width of $110 \mathrm{~cm}$ and height of $100 \mathrm{~cm}$. And sheet metals are used $3 \mathrm{~mm}$ think with the tank of sugar beet. The machine has four-rubber tire wheel diameter of $30 \mathrm{~cm}$. The machine was fabricated with locally available materials at the Manufacture Center of Kafrelsheikh.

Table 1. The technical specifications of prototype harvester machine

\begin{tabular}{|l|l|}
\hline specifications & value \\
\hline Total length, $\mathrm{cm}$ & 200 \\
\hline Total width, $\mathrm{cm}$ & 100 \\
\hline Total height, $\mathrm{cm}$ & 150 \\
\hline Total mass, $\mathrm{kg}$ & 350 \\
\hline Number of rows & 1 \\
\hline Source of power & P.T.O. tractor \\
\hline hitching & Three points \\
\hline Share shape & Saw-toothed wheel \\
\hline Share diameter, cm & 20 \\
\hline Distance between rows, cm & 50 \\
\hline
\end{tabular}

The second stage in the present investigation was carried out at Almorabin village, Kafrelsheikh Governorate during agricultural season of 2010 - 2011. In this experiment, Beta poly variety was used and the total planted area was about 3 feddans. The soil mechanical analysis is show in table 2

Table 2. shows the soil mechanical analysis.

\begin{tabular}{|c|c|c|c|c|}
\hline \multirow{2}{*}{ The Season } & \multicolumn{3}{|c|}{ Soil components \% } & \multirow{2}{*}{ Soil } \\
\cline { 2 - 5 } & Clay & silt & sand & clay \\
\hline $2010-2011$ & 58 & 30 & 12 & \\
\hline
\end{tabular}


- Moisture content: The soil moisture content was determined by the standard oven method .the samples were taken from different to constant weight at $105 \mathrm{C}^{\circ}$ for 24 hours. The soil moisture was determined, based on wet mass, as follows:

$$
\mathrm{M} . \mathrm{C}=\frac{\mathrm{M} 1-\mathrm{M} 2}{\mathrm{M} 1} \times 100, \quad \ldots \ldots \ldots \ldots . .1
$$

Were:

$$
\begin{aligned}
\text { M.C. } & =\text { Moisture content } \%, \\
\text { M1 } & =\text { mass before drying }, g \text { and } \\
\text { M2 } & =\text { mass after drying }, g
\end{aligned}
$$

\subsection{Specifications of the Sugar beet harvesting machine}

the machine parts consists of frame was had The min outer dimensions of $200 \mathrm{~cm}$ length $\times 100 \mathrm{~cm}$ width $\times 100 \mathrm{~cm}$ height, includes elements to fix a hitching system, gear box, parts of power train, lifting unit, beet conveyer unit, removing the leaves unit, beet elevator unit and beet collecting tank

1.2 Tractor model: A Nasr tractor $60 \mathrm{hp}$ was used is this experimentation. A The power was transmitted from the tractor to the machine gearbox through P.T.O. shaft.

\section{2- METHOD}

\subsection{Investigated Variables}

1- Tractor forward speed : four forward speed levels of 2.16, $2.88,3.66$ and 4.32 $\mathrm{km} / \mathrm{h}$.

2- Topping knife speed levels of 3.1, 4.3, 5.5 and $6.2 \mathrm{~m} / \mathrm{s}$.

3- Harvesting depth was deduced as constant at $0.30 \mathrm{~m}$ for all treatments.

4- Soil moisture content: experiments were carried out at different soil moisture content of 30, 24 and $18 \%$ (w.b.)

\subsection{Measurements}

Field measurements were carried out to determine the following:

2.2.1. Effective field capacity: it was calculated by using the following formula (kepner et. al., 1982)

Where:

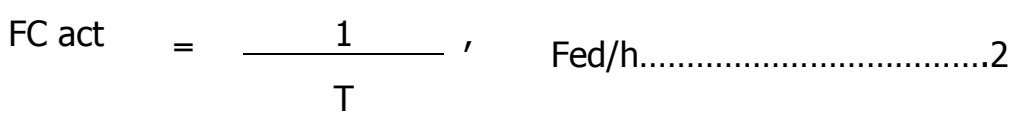

$\mathrm{FC}$ act $=$ Actual field capacity of the harvesting machine.

$$
\begin{aligned}
& \mathrm{T}=\text { Total time per feddan, } \mathrm{h} . \\
& \text { Also, } \mathrm{T}=(\mathrm{t}+\mathrm{t} 1+\mathrm{t} 2+\mathrm{t} 3+\ldots .) \ldots .
\end{aligned}
$$

Where: 
$\mathrm{t}=$ Theoretical time,

$\mathrm{t} 1+\mathrm{t} 2+\mathrm{t} 3=$ Time lost for turning + Time lost for adjusting + Time lost for repairing.

\subsubsection{Lifting efficiency, $\%$}

The term of lifting efficiency could be defined as the percentage of lifted sugar beet roots based on total mass of beet on the experimental unit. The lifting efficiency was calculated according to the following equation:

Where:

$$
\begin{aligned}
& \text { Le }=\text { lifting efficiency, } \% \\
& M_{L}=\text { the mass of lifted beets, } \mathrm{kg} \text { and } \\
& M_{T}=\text { the total mass of beet (lifted + unlifted), } \mathrm{kg} .
\end{aligned}
$$

\subsubsection{Topping efficiency, $\%$}

it was determined by using the following formula (Richey et. al. ., 1961) Topping efficiency, $\%=100-$ (untopped beet, $\%+$ broken beet, $\%$ )....... 5 Where :

Un topped
beet $\quad \begin{gathered}\text { No. of un topped beet } \\ \text { Total No. of topped beet }+ \text { No. } \\ \text { of un topped beet }\end{gathered} \%$ 100, $\%$...6

$$
\text { Broken beet }=\frac{\text { No. of broken beet }}{\text { Total No. of topped beet }} \times 100, \% \quad \ldots . .7
$$

\subsubsection{Harvester efficiency, $\%$}

Harvester efficiency mean the undamaged sugar beet roots lifted over the soil surface by sugar beet harvester. The harvester efficiency was calculated according to the following equation:

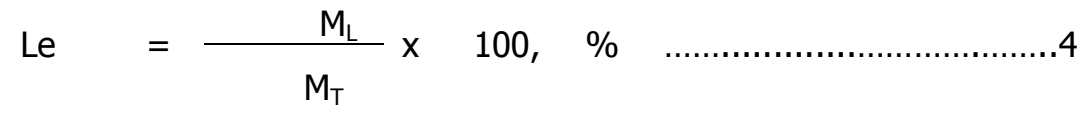

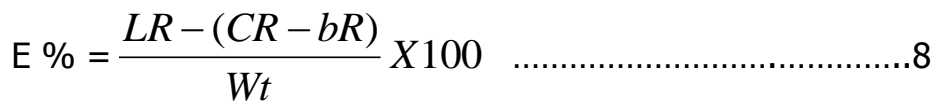

$$
\begin{aligned}
& \mathrm{CR}=\text { cut roots, ton } / \text { fed. } \quad \mathrm{bR}=\text { buried roots, ton } / \text { fed. }
\end{aligned}
$$


2.2.6. Specific fuel consumption: Required power can be calculated by using the following formula (Hunt, 1983)

$E P=[f . c(1 / 3600) \rho E \times$ L.C.V. $\times 427 \times \eta$ thb $\times \eta m \times 1 / 75 \times 1 / 1.36], k W \ldots 12$

Where:

,EP = required power, $\mathrm{kW}$

,f.c $=$ the fuel consumption, $\mathrm{l} / \mathrm{h}$

,$\rho \mathrm{E}=$ density of the fuel, $\mathrm{kg} / \mathrm{l}$ (for solar fuel $=0.85$ )

,L.C.V = lower calorific value of fuel (for solar fuel is $11000 \mathrm{kcal} / \mathrm{kg}$ )

$427=$ thermal- mechanical equivalent, $(\mathrm{w} / \mathrm{kcal}$.$) ,$

$\eta$ thb $=$ thermal efficiency of the engine( $35 \%$ for Diesel), and

$\eta \mathrm{m}=$ mechanical efficiency of the engine( $80 \%$ for diesel).

Specific fuel

consumption

2.2.7- Sugar beet harvesting cost: operation cost was determined including fixed and operating costs. Declining balance method was used to determine the depreciation (Hunt, 1983).

Operating cost

$$
=\frac{\text { Machine cost , L.E/h }}{\text { Yield output, ton/h , }}
$$

\section{RESULTS AND DISCUSSION}

\section{1- Effective field capacity}

Results data presented in Fig.3 illustrate the effect of forward speed on effective field capacity at different leaves of soil moisture content. It can be noticed that increasing forward speed from 2.16 to $4.32 \mathrm{~m} / \mathrm{s}$ and decreasing soil moisture content from 30 to $18 \%$ tends to increase the effective field capacity. It's clear that the increasing forward speed from 2.16 to $4.32 \mathrm{~m} / \mathrm{s}$ at moisture content of $30 \%$ tends to increase the effective field capacity from 0.30 to $0.36 \mathrm{fed} / \mathrm{h}(+16.6 \%)$. While, decreasing soil moisture content from 30 to $18 \%$ w.b., at forward speed of $2.16 \mathrm{~m} / \mathrm{s}$ the effective field capacity increased from 0.30 to 0.32 fed $/ \mathrm{h}(+6.25 \%)$. The maximum value of effective field capacity was $0.48 \mathrm{fed} / \mathrm{h}$, recorded on soil moisture content of $24 \% w . b$, and forward speed of $4.32 \mathrm{~km} / \mathrm{h}$. As increase the speed of the harvest will lead to increase the performance rate of the machine. Also lower moisture 
content of the soil reduces the cohesion of root with soil. Consequentially making it easier to uproot the machine with low resistance becoming more and more production capacity of the machine.

\section{2 - Uprooting efficiency}

From means of uprooting efficiency, it is clear that decreasing forward speed or soil moisture content tends to increase uprooting efficiency. As shown in Fig. 4 it can be found that, harvesting sugar beet at soil moisture content of $30 \% \mathrm{w} . \mathrm{b}$, and as increasing forward speed from 2.16 to $4.32 \mathrm{~km} / \mathrm{h}$ tend to decrease uprooting efficiency from 91.8 to $89.8 \%(-2.18 \%)$. While, at forward speed of $2.16 \mathrm{~km} / \mathrm{h}$ by decreasing soil moisture content from 30 to $18 \%$ w.b, uprooting efficiency tends to decrease from 91.8 to $90.5 \%(-1.4 \%)$. generally, results showed that the maximum uprooting efficiency value was $92.6 \%$ recorded on soil moisture content of $18 \%$ w.b, and forward speed of $2.16 \mathrm{~km} / \mathrm{h}$. And that's where the low moisture content of the soil increases the speed of the machine and splits of soil blocks are easy to improves the performance of the machine while increasing the speed of the machine from the border safe, they lead to damage and cracking in the roots.

\begin{tabular}{|l|l|l|l|l|l|l|}
\hline & \\
\hline
\end{tabular}




\section{3- Harvester efficiency, \%}

the obtained data in Fig. $\mathbf{5}$ indicate in general that, increasing forward speed level or decreasing soil moisture content level of tend to decrease the percentage of harvesting efficiency. While, increasing of topping knife speed level tend to increase of harvesting efficiency. So, it can be seen that at forward speed of $2.16 \mathrm{Km} / \mathrm{h}$ and soil moisture content of $30 \%$ w.b, by increasing topping knife speed from 3.1 to $6.2 \mathrm{~m} / \mathrm{s}$. the harvesting efficiency increased from 82.8 to $88.9 \%(+7.4 \%)$. While, at soil moisture content of $30 \% \mathrm{w} . \mathrm{b}$, and topping knife speed of $3.1 \mathrm{~m} / \mathrm{s}$ by increasing forward speed from 2.16 to $4.32 \mathrm{Km} / \mathrm{h}$, the harvesting efficiency decreased from 82.8 to $81.1 \%(-2.1 \%)$. Also, with decreasing soil moisture content from $30 \%$ to $18 \%$ at forward speed of $2.16 \mathrm{Km} / \mathrm{h}$ and topping knife speed from 3.1 harvesting efficiency decreased from $82.8 \%$ to $76.8 \%(-7.2 \%)$. On the other hand, maximum harvesting efficiency of $88.9 \%$ was obtained at forward speed of $2.16 \mathrm{Km} / \mathrm{h}$, knife speed of 6.2 $\mathrm{m} / \mathrm{s}$ and soil moisture content of $30 \%$ w.b. While, minimum harvesting efficiency of $75.2 \%$ recorded at forward speed of $4.32 \mathrm{Km} / \mathrm{h}$, knife speed of $3.1 \mathrm{~m} / \mathrm{s}$ and soil moisture content of $18 \%$ w.b.

\section{5- Topping efficiency}

Data indicates that increasing forward speed led to decrease topping efficiency while increasing topping knife speed and decreasing soil moisture content led to increasing topping efficiency, as shown in Fig. 6. On the whole results recorded maximum value of topping efficiency at soil moisture content of $18 \%$ w.b. So, at using moisture content of $18 \%$ w.b and topping knife speed of $3.1 \mathrm{~m} / \mathrm{s}$, increasing forward speed from 2.16 to $4.32 \mathrm{~km} / \mathrm{h}$ result in decreasing topping efficiency from 95.5 to $94.4 \%$ ($1.15 \%)$.While, at the same previous condition of soil moisture content and forward speed of $2.16 \mathrm{~km} / \mathrm{h}$, increasing topping knife speed from 3.1 to $6.2 \mathrm{~m} / \mathrm{s}$ caused that, increasing topping efficiency from 95.5 to $97.9 \%$ ( $+2.51 \%)$. Finally, the high value of topping efficiency was $97.9 \%$ registered with soil moisture content of $18 \%$ w.b, forward speed of $2.16 \mathrm{~km} / \mathrm{h}$ and topping knife speed of $6.2 \mathrm{~m} / \mathrm{s}$. 


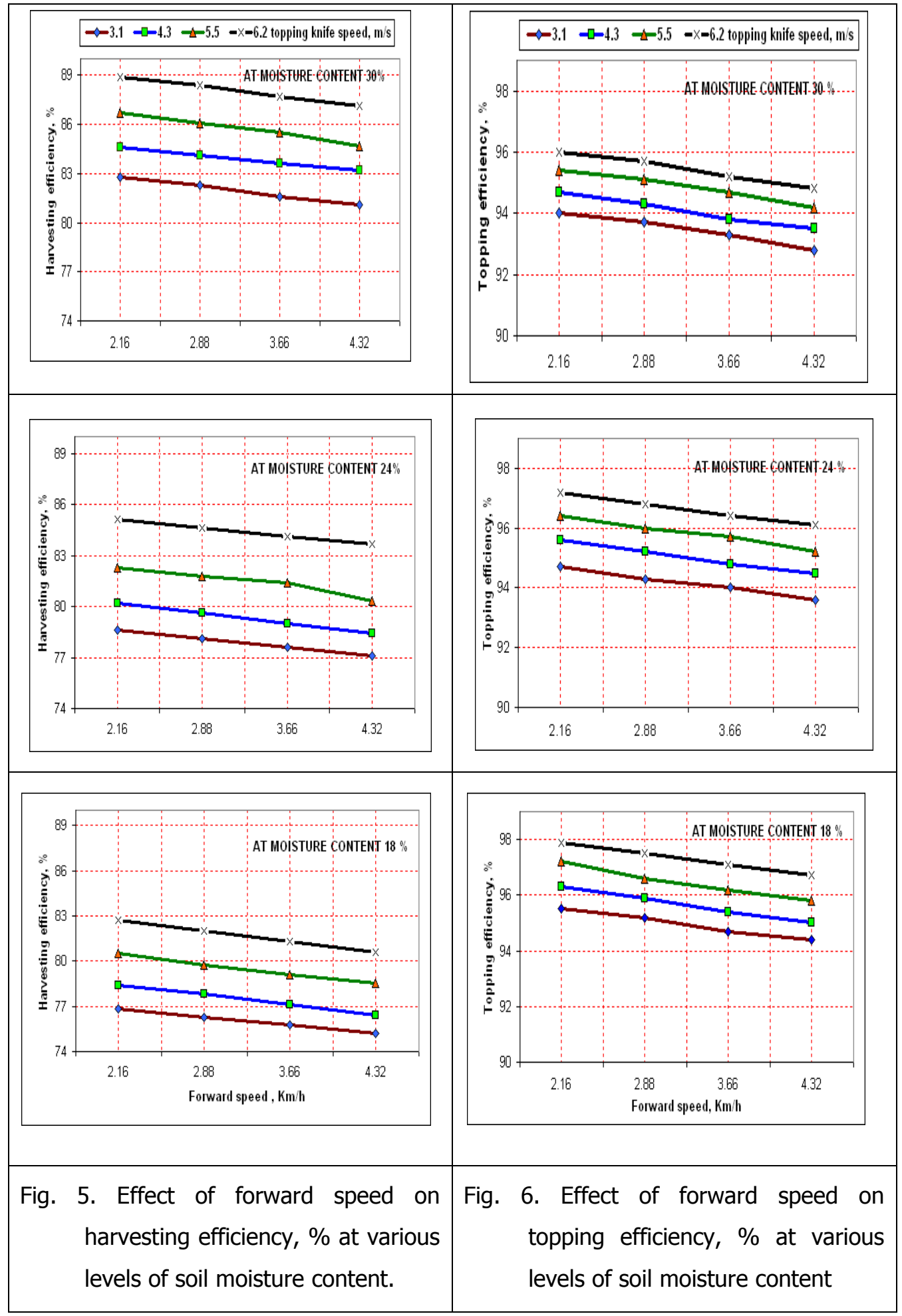

\section{5- Specific fuel consumption, I/ kW.h}

the obtained data in Fig. 7 indicated that, specific fuel consumption was decreased with increasing forward speed, topping knife speed and decreasing soil moisture content levels. Where, specific fuel consumption decreased from 0.825 to 0.778 l/kW.h $(-5.7 \%)$ by increasing forward speed from 2.16 to $4.32 \mathrm{Km} / \mathrm{h}$ at knife speed 
$3.1 \mathrm{~m} / \mathrm{s}$ and soil moisture content of $30 \%$ w.b. Also, increasing topping knife speed from 3.1 to $6.2 \mathrm{~m} / \mathrm{s}$ at forward speed of $2.16 \mathrm{Km} / \mathrm{h}$ and soil moisture content of $30 \%$ w.b. tend to decrease specific fuel consumption from 0.825 to $0.697 \mathrm{l} / \mathrm{kW} . \mathrm{h}$ ( -15.5 \%).Also, decreasing soil moisture content from $30 \%$ to $18 \%$ at forward speed of 2.16 and topping knife speed of $3.1 \mathrm{~m} / \mathrm{s}$, specific fuel consumption decreased from 0.825 to $0.686 \mathrm{l} / \mathrm{kw} . \mathrm{h}(-16.8 \%)$. On the other wise, the minimum value of specific fuel consumption was $0.517 \mathrm{l} / \mathrm{kW} . \mathrm{h}$ recorded with soil moisture content of $18 \%$ w.b, forward speed of $4.32 \mathrm{~km} / \mathrm{h}$ and topping knife speed of $6.2 \mathrm{~m} / \mathrm{s}$. Through experiments it was observed that $24 \%$ moisture content is best suited in the consumption of energy where the soil has a well-suited for the harvest, where they are not sticky and not dry, so it was then the performance of the machine does not require extra energy to overcome the soil conditions.

\section{6 - Total operation cost, L.E./ fed}

Data presented in Fig. 8 showed that, total operation cost was decreasing with increasing both of forward speed and knife speed and with decreasing soil moisture content levels. Where, increasing forward speed from 2.16 to $4.32 \mathrm{Km} / \mathrm{h}$ at topping knife speed of $3.1 \mathrm{~m} / \mathrm{s}$ and soil moisture content of $30 \%$ w.b. , total operation cost decrease from 94 to 80 L.E./ fed (-14.9\%). Also, increasing the knife topping speed from 3.1 to $6.2 \mathrm{~m} / \mathrm{s}$ tends to decrease the harvesting cost from 94 and 85 L.E./fed ( $9.5 \%$ ) at forward speed of $2.16 \mathrm{Km} / \mathrm{h}$ and soil moisture content of $30 \% \mathrm{w} . b . a l s o$, with decreasing soil moisture content from $30 \%$ to $18 \%$ at forward speed of $2.16 \mathrm{~km} / \mathrm{h}$ and topping knife speed of $3.3 \mathrm{~m} / \mathrm{s}$, the harvesting cost from 94 to $101 \mathrm{~L} . \mathrm{E} /$ fed (+7.4\%) Results showed also that, minimum value of harvesting cost was 72 L.E./fed recorded at using forward speed of $4.32 \mathrm{Km} / \mathrm{h}$, harvesting topping knife speed of $6.2 \mathrm{~m} / \mathrm{s}$ and soil moisture content of $30 \%$ w.b. While, maximum value was 101 L.E./fed recorded at forward speed of $2.16 \mathrm{~km} / \mathrm{h}$, harvesting topping knife speed of $3.1 \mathrm{~m} / \mathrm{s}$ and soil moisture content of $18 \% \mathrm{w}$. 


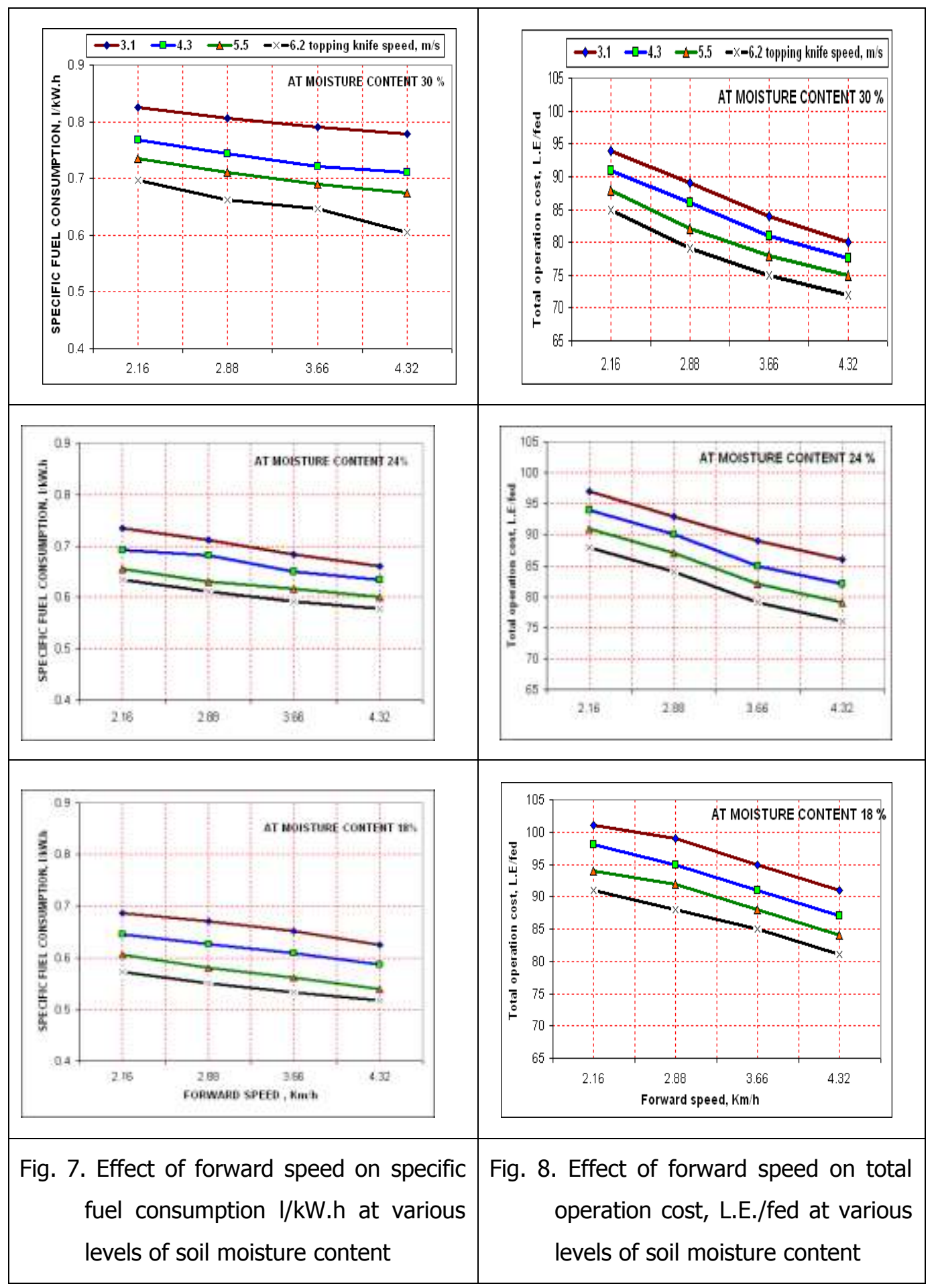




\section{CONCLUSION}

\section{The obtained results can be concluded as follows}

1- At determination effective field capacity for manufactured harvesting machine. It was agreed directly with forward speed and topping knife speed. While it were reversely relation with soil moisture content.

2- The maximum value of field capacity was $0.48 \mathrm{fed} / \mathrm{h}$ recorded at using forward speed of $4.32 \mathrm{~km} / \mathrm{h}$ and soil moisture content of $18 \%$ w.b.

3- Uprooting efficiency was agreed reversely with forward speed and soil moisture content. While, it was directly with topping knife speed. On the other hand, maximum value of lifting efficiency was $92.6 \%$ recorded at forward speed of 2.16 $\mathrm{km} / \mathrm{h}$ and soil moisture content of $18 \%$ w.b.

4- Maximum value of topping efficiency was $97.9 \%$ recorded with forward speed 2.16 $\mathrm{km} / \mathrm{h}$, topping knife speed of $6.2 \mathrm{~m} / \mathrm{s}$ and soil moisture content of $18 \%$ w.b.

5- Specific fuel consumption was agreed reversely relation with forward speed, topping knife speed and harvesting depth and agreed reversely relation with soil moisture content. Minimum value of specific fuel consumption was $0.517 \mathrm{l} / \mathrm{kW} . \mathrm{h}$ recorded with soil moisture content of $18 \%$ w.b, forward speed of $4.32 \mathrm{~km} / \mathrm{h}$ and topping knife speed of $6.2 \mathrm{~m} / \mathrm{s}$

6- Minimum value of total operation cost for harvesting was 72 L.E./fed at forward speed $4.32 \mathrm{Km} / \mathrm{h}$, knife speed $6.2 \mathrm{~m} / \mathrm{s}$ and soil moisture content of $30 \%$ w.b.

\section{REFERANCES}

1. Abd-Rabou. A.F. 2004. Manufacturing a small machine to suit harvesting sugar beet under Egyptian conditions. Ph.D., Thesis. Agric. Mech. Dept., Fac. Agric., Kafrelsheikh. Tanta Univ.

2. Abo- shieshaa, R.R. 2001. A study on mechanical topping of sugar beet under Egyptian conditions. Misr J. Eng., 18(3): 569 -584.

3. Agricultural statistics. 2008. Ministry of Agriculture, Cairo, Egypt. (1):48.

4. Allam, M.N., A.H. Nour and M.A. Farag. 1988. Prospective of sugar beet mechanical growing . Agric. Rec. Review in Egypt. , 66(3):537- 543.

5. Bahnas, O.T. 2006. The mechanical sugar beet harvest requirements in the reclaimed lands. The 14th Annual Conference of the Misr Society of Agr. Eng., New trends in Agric. Eng. :909-928.

6. Bentini M, C. Caprara and V. Rondelli. 2005. Mechanical properties of sugar beet roots. Transactions of the ASAE. Vol. 48(4): 1429-1439. 
7. Elbanna E.B. , Z. I. Ismail and A. E. Abou El-Magd. 2010.Development planting and harvesting sugar beet crop machine. J. Soil Sci. and Agric. Engineering, Mansoura Univ., Vol.1 (8):895 - 919.

8. Hunt, D. 1983. Farm power and machinery management. $8^{\text {th }}$ Ed. Iowa state Univ., Press Ames,Iowa, USA: 364-368

9. Kepner, R.A., R.Bainer and E.I. Barger. 1982. Principles of farm machinery .handbook, $3^{\text {rd }}$-ed-cbc publisher, distributors, India: 464 - 468.

10. Mady, M.A. 2001. Mechanization for some operations for sugar beet production. Misr J. Ag. Eng., 18(2): 339 -355.

11. Morad, M.M., G.H.El-said, M.M.A.El-sharabasy and F.A. Abd elgawad. 2007. Comparative study between manual and mechanical methods of harvesting sugar beet crop. Misr J. Ag. Eng., 24(4): 793 -813.

12. Richey, C.B., P.Jacobson and C.W. Hall. 1961. Agricultural Eng., Handbook. Mcgrow-Hillbook Company. INC. NewYork, Toronto, London: 270-275. 


\section{تصنيع آلة بالخامات المحلية لتناسب حصاد بنجر السكر

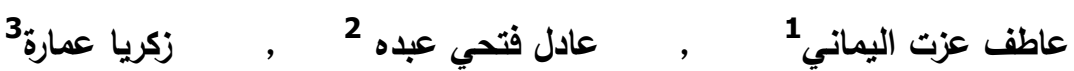 \\ قسم بحوث ميكنة العمليات الزراعية - معهد بحوث الهندسة الزراعية- الدقي - الجيزة - مصر.}

يعتبر محصول بنجر السكر من المحاصيل السكرية الاستراتيجية الهامة في مصر و يعتبر من

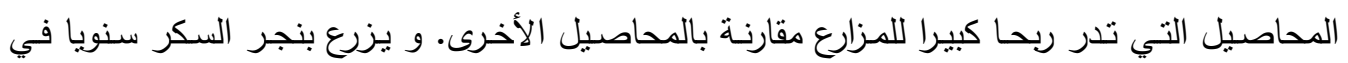

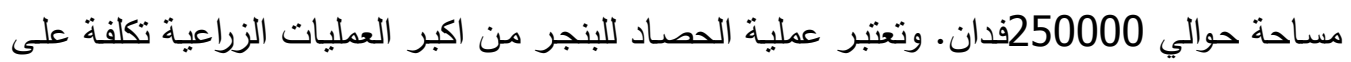

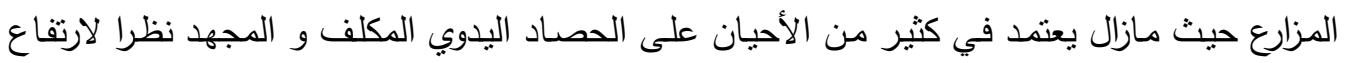

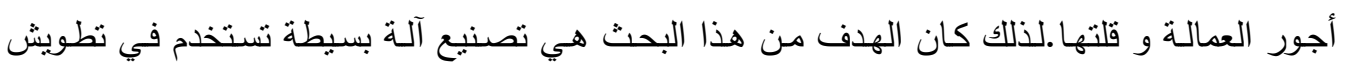

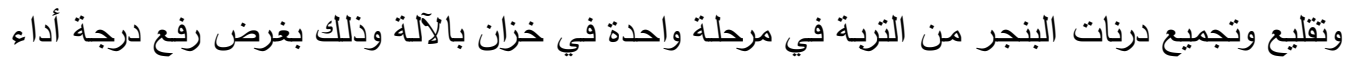

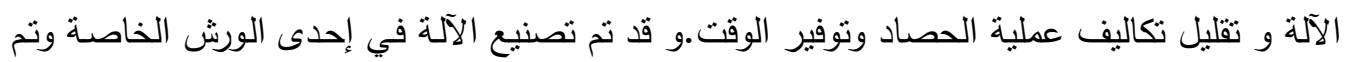
تقييم أدائها إثناء العمل بمنطقة المرابعين بكفر الثيخ.وقد اشتملت الدراسة على تجربة العوامل المؤثرة على أداء آلة الحصاد مثل السرعة الأمامية وتم استخدام أربع سرعات أمامية هي 2.16 - 2.88 - 2.16 -

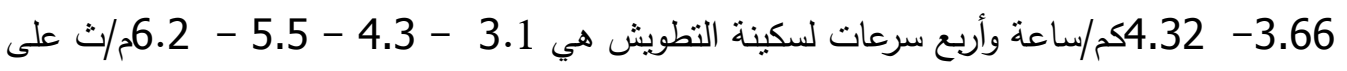

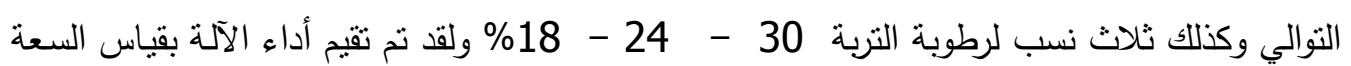

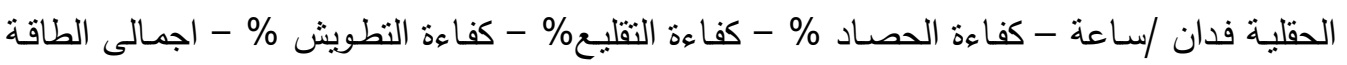
المستهلكة ( كيلووات.ساعة / فدان ) واجمالى التكاليف للفدان (جنية/فدان) وكانت أهم النتائج:

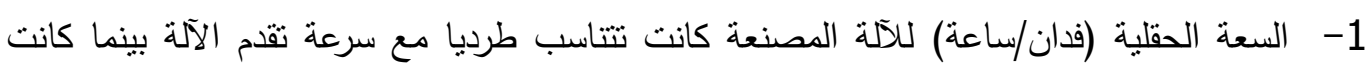

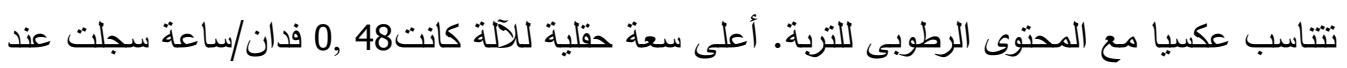
استخدام سرعة تقدم 4,32 كم / ساعة و محتوى ر طوبى للتربة 24 \% . 2 - كفاءة الحصاد (\%) كانت تتتاسب طرديا مع سرعة التقدم و سرعة سكينة النطويش وبلغت أعلى قيمة لها 88.9 \% سجلت عند استخدام سرعة تقدم 2,16 كم/ساعة , سرعة سكينة التطويش 2, 6 م/ث و محتوى ر طوبى 24 3 - كفاءة التطويش (\%) كانت تنتاسب عكسيا مع سرعة التقام ومع المحتوى الرطوبى للتربة وطرديا مع سرعة سكينة النطويش وبلغت أعلى قيمة لها

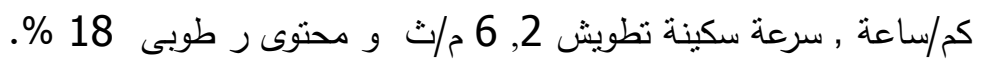
4 - كفاءة التقليع (\%) كانت تنتاسب عكسيا مع سرعة التقدم و كانت أعلى قيمة لكفاءة التقليع 6 , 92

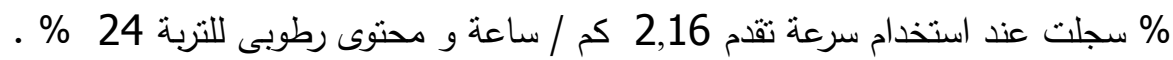

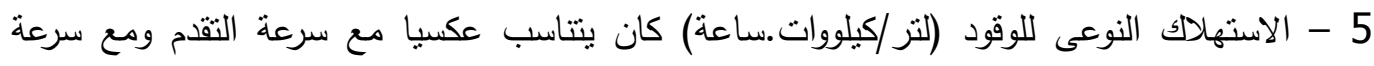

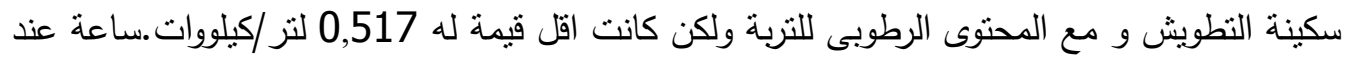
محتوى رطوبى 18\% مع عند استخدام سرعة تقدم 4,32 كم / ساعة , سرعة سكينة تطويش 2, 6 
6- تكاليف الحصاد(جنية/فدان) كانت نتتاسب عكسيا مع سرعة التقدم و سرعة سكينة التطويش و مع المحتوى الرطوبى للتربة و بلغت اقل قيمة لها 72 جنية/فدان عند استخدام سرعة تقدم 4,32 كم / ساعة , سرعة سكينة نطويش 2, 6 م/ث و محتوى رطوبى للتربة 30 \% .

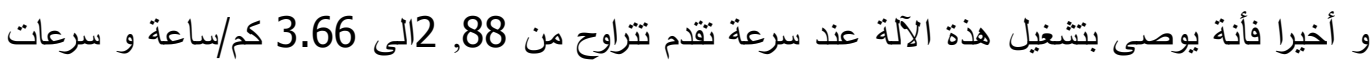

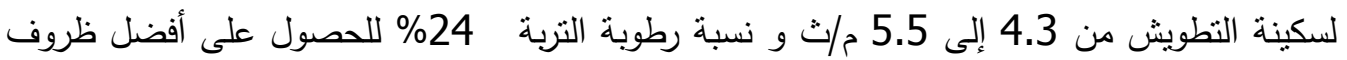

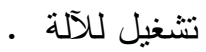

2,1 باحث بمعهذ بحوث الهندسة الزراعية - الدقى - الجيزة 3- رئيس بحوث بمعهد بحوث الهندسة الزراعية - الدقى - الجيزة 